УДК 33.338 .2

DOI: https://doi.org/10.37320/2415-3583/12.13

Присвітла О.В.

кандидат економічних наук, доцент кафедри економіки та організації виробництва, Дніпровський державний технічний університет ORCID: https://orcid.org/0000-0002-5751-5609

\title{
ФРАНЧАЙЗИНГ: СУТНІСТЬ ТА ОРГАНІЗАЦЙНИЙ ПОРЯДОК ВІДОБРАЖЕННЯ ПАРТНЕРСЬКИХ ВІДНОСИН
}

Стаття присвячена проблемам і перспективам розвитку франчайзингу в Україні. Світова економіка характеризується високим ступенем глобалі-зації та інтеграції, тому постає необхідність активізації інноваційної діяль-ності, а налагодження тісного торговельного, інвестииійного та коопера-иійного співробітництва сприятиме включенню в процес формування но-вих моделей економічного розвитку, основою яких стане оновлення еко-номічних систем на основі технологічної модернізаціі. Актуальність здо-бувають нетрадиційні методи фінансування інноваційної діяльності, до числа яких належить франчайзинг. У статті розкрито сутність франчайзингових відносин, досліджено розвиток франчайзингу в Украйні, а також механізм здійснення франчайзингових відносин. Визначено переваги та недоліки для основних суб 'єктів франчайзингових відносин. Обтрунтовано необхідність та значення організації бізнесу на умовах франчайзингу.

Ключові слова: франчайзинг, франчайзер, франчайзі, франчайзингові відносини, організаційний механізм франчайзингу.

Постановка проблеми. Стан сучасного бізнессередовища характеризується загостренням конкуренції на споживчих ринках, необхідністю залучення прямих іноземних інвестицій, тому особливої гостроти набуває питання активізації інноваційно-інвестиційної політики. Враховуючи сучасні кризові явища в економіці України, а саме обмеженість бюджетних коштів, відсутність фінансування, а також досконалої системи кредитування та страхування, слід відзначити, що франчайзинг є однією 3 перспективних форм бізнесу на українському ринку. Франчайзинг - одна 3 найефективніших форм міжнародної економічної діяльності, за рахунок залучення прямих іноземних інвестицій, передових технологій є можливість підвищити конкурентоспроможність країни загалом.

Аналіз останніх досліджень та публікацій. Дослідженнями, присвяченими такій формі ділового співробітництва, як франчайзинг, займалися такі зарубіжні вчені, як Ж. Дельта, Ф. Котлер, Ж. Ламбен, М. Мендельсон, С. Шейн. Дослідженням використання передових технологій в економічному розвитку держави займаються такі науковці, як Дж. Данінг, Р. Лукас, Й. Шумпетер. Дослідженню організаційно-економічного механізму франчайзингу присвячені роботи Т.М. Григоренко, О.О. Зеркіна, Ю.С. Кравцова, С.М. Махнуша, Н.І. Нечивілова, С.В. Огінок, Ю.Б. Федунь та ін. Але не всі питання були повністю розкриті, що і зумовлює необхідніть проводити подальші дослідження цієї сфери.

Метою статті $\epsilon$ дослідження сутності франчайзингу як чинника впливу на трансфер технологій, як складника інвестиційної політики, а також виявлення стримуючих факторів, які гальмують розвиток франчайзингу в країні, вивчення організаційних особливостей франчайзингу.

Виклад основного матеріалу. Сучасний ринок технологій охоплює різні сфери міжнародних економічних відносин. В умовах розвитку світо-вої економіки залучення технологій розглядають як головний чинник зростання економік як розвинених країн, так і країн, що розвиваються. Активна участь на міжнародному ринку технологій $є$ запорукою доступу до передових знань, стимулювання внутрішньої інноваційної діяльності, підвищення продуктивності економічних процесів. Економічні реформи - це насамперед реформи щодо модернізації України. Першочерговим пріоритетом є створення сприятливого інвестиційного клімату, адже це не тільки фінансові ресурси для розвитку економіки, а й нові технології, ноухау, робочі місця, освоєння нових ринків тощо. Одним із важливих факторів конкурентоспроможності економіки є система трансферу знань та технологій. Така система спонукає до адаптації, абсорбції та дифузії знань і технологій у суспільстві загалом, підвищення якості життя, збагачує технологічний базис держави, спонукає до формування технічного досвіду, стимулює промисловість та забезпечує конкурентоспроможність країни, формує передумови до генерації знань тощо. Франчайзинг $є$ одним із найбільш гнучких і мобільних інструментів передачі технологій та векторів у вирішенні проблем стагнації економіки. У вітчизняному бізнес-середовищі росте інтерес до використання франчайзингу як концепції швидкого та ефективного розширення підприємницької діяльності. За даними консалтингової компанії Franchise Group, у США близько 80\% малого та середнього бізнесу працює на умовах франчайзингу, в Європі - 67\%, а в Україні - лише 23\% [1]. Рівень розвитку франчайзингу в США характеризується такими даними: функціонує понад 2200 франшизних систем у понад 75 видах діяльності; кількість франшизних підприємств досягає майже 855,0 тис. од.; на одного франчайзера доводиться в середньому 388 франшизних точок; франчайзингові компанії забезпечують 9,5 млн робочих місць і виробляють близько 850 млрд дол. продукції для національної економіки [2].

Згідно з даними FRANCHISE GROUP, на середину 2019 року в Україні спостерігається ріст франчайзингу на 18\% щодо аналогічного періоду минулого року, окрім того, збільшується кількість світових брендів фран- 
чайзерів, які зацікавлені у своєму розвитку на ринку України (рис. 1). Зокрема, в Україні в 2016 р. франшизу продавала 461 компанія, 63\% цих франшиз належать українським компаніям, які працюють на ринку більше трьох років. Кількість франчайзингових компаній скоротилася порівняно з 2014 р. (565 компаній), що свідчить про вихід із ринку дрібних і «фейкових» франшиз і стійкість великих компаній. Окрім того, частка українських франшиз продовжує стабільно збільшуватися, що свідчить про розвиток саме українського франчайзингу. Так, у 2017 році налічувалося 268 із загальної кількості 361, у 2018 році - 325, у 2019 році - 390. Безумовно, в Україні низький рівень частки франчайзингу порівняно із зарубіжними показниками, але майже кожного року простежується позитивна тенденція приросту франчайзерів. Франчайзинговий ринок надає великі переваги для економіки України. Він може стати початком для розвитку дрібних і спільних підприємств, які займатимуться інноваційною діяльністю.

Останніми роками сформувалося кілька тенденцій, притаманних єв-ропейському франчайзингу: збільшення франчайзингових підрозділів усередині мережі, тобто дедалі більша кількість франчайзі намагається відкрити якнайбільше точок свого франчайзера; посилюється інтернаціоналізація європейського франчайзингу; збільшення використання новітніх технологій; створення франчайзингових асоціацій у кожній країні Європи [8].

Проте, термін «франчайзинг» $є$ досить новим для української економіки і недостатньо врегульованим законодавчо. Правові засади франчайзингової діяльності регламентовано Господарським Кодексом (Глава 36 Комерційна концесія) [3], Цивільним Кодексом України (Глава 76-Використання у підприємницькій діяльності прав інших суб'єктів господарювання (комерційна концесія)) [4]. Згідно з цими актами, які регулюють відносини комерційної концесії, закріплені різні норми однойменного договору. Відповідно до ч. 1 ст. 1115 ЦК України за договором комерційної концесії одна сторона (правоволоділець) зобов'язується надати другій стороні (користувачеві) за плату право користування відповідно до її вимог комплексом належних цій сто- роні прав із метою виготовлення та (або) продажу певного виду товару та (або) надання послуг. Натомість у ГК України міститься інакше легальне визначення поняття договору комерційної концесії, за яким одна сторона (правоволоділець) зобов'язується надати другій стороні (користувачеві) на строк або без визначення строку право використання в підприємницькій діяльності користувача комплексу прав, належних правоволодільцеві, а користувач зобов'язується дотримуватися умов використання наданих йому прав та сплатити правоволодільцеві обумовлену договором винагороду (ч. 1 ст. 366). Чинним вітчизняним законодавством установлені єдині вимоги щодо форми договору комерційної концесії. Згідно 3 ч. 1 ст. 1118 ЦК України, договір комерційної концесії укладається у письмовій формі; у ч. 1 ст. 367 ГК України, відповідно до якої договір комерційної концесії повинен бути укладений у письмовій формі у вигляді єдиного документа; недодержання цієї вимоги тягне за собою недійсність вказаного договору. 3 огляду на законодавство зарубіжних країн (Франція, Бельгія, Швейцарія), комерційна концесія - це договір про передачу виняткового права на продаж товарів (так звані дистриб'юторські угоди) [5]. Слід також зазначити, що основним механізмом, який регулює франчайзингову діяльність у світі, є Кодекс етики франчайзингу [6], а також законодавчі норми, що діють на території Європейського Союзу, наприклад документ, який регламентує відносини франчайзингу на території $\mathrm{CC},-$ Регламент № 330/2010 (чинний до 2022 р.) [7]. Тому адаптація українського законодавства у визначенні поняття «франчайзинг» замість поняття «комерційна концесія» відповідала б нормам ЄС, а також сприяла б розвитку інвестиційної активності 3 боку іноземних компаній.

Франчайзингові відносини виступають своєрідним каналом передачі технологічних, маркетингових та організаційних інновацій, у своій струк-турі взаємозв'язку поєднують елементи різних видів економічних відносин, таких як інвестування, оренда, трансфер технологій, ліцензування, надання послуг тощо, з огляду на це франчайзинг можна розглядати, як спосіб фінансування інноваційно-інвестиційної

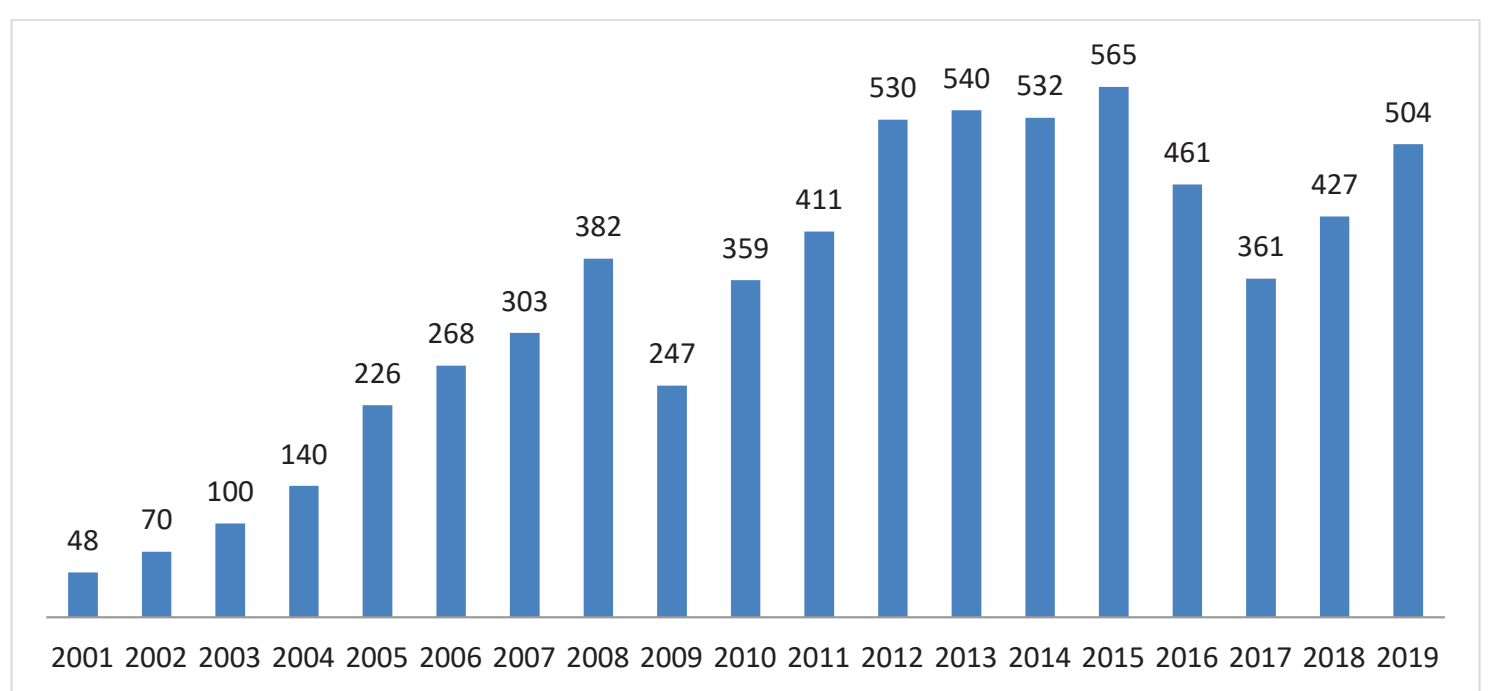

Рисунок 1 - Кількість франчайзерів на ринку України [1] 
діяльності суб'єктів господарювання. Сучасні реалії спонукають підприємців до конкурентної боротьби на сучасних ринках технологій, тому постає необхідність придбання франшиз, ліцензій, прав на виробництво продукції, використання технологій та іншої інтелектуальної власності.

Схематично порядок організації франчайзингового бізнесу наведено на рис. 2. По-перше, необхідно визначити пріоритетний напрям, який буде максимально наближений до життєвих інтересів, а також можливість і терміни отримання прибутку. У країнах, де франчайзинг глибоко пустив коріння і широко використовується у різних сферах бізнесу, як правило, законодавство висуває жорсткі умови до франчайзера щодо отримання інформації своїм потенційним франчайзі. Наступним кроком $є$ вибір франчайзера, основним завданням якого є систематизація інформації, зокрема: імідж, порівняльна вартість франшизи, необхідний обсяг стартового капіталу, очікуваний період окупності бізнесу, обсяги підтримки франчай-

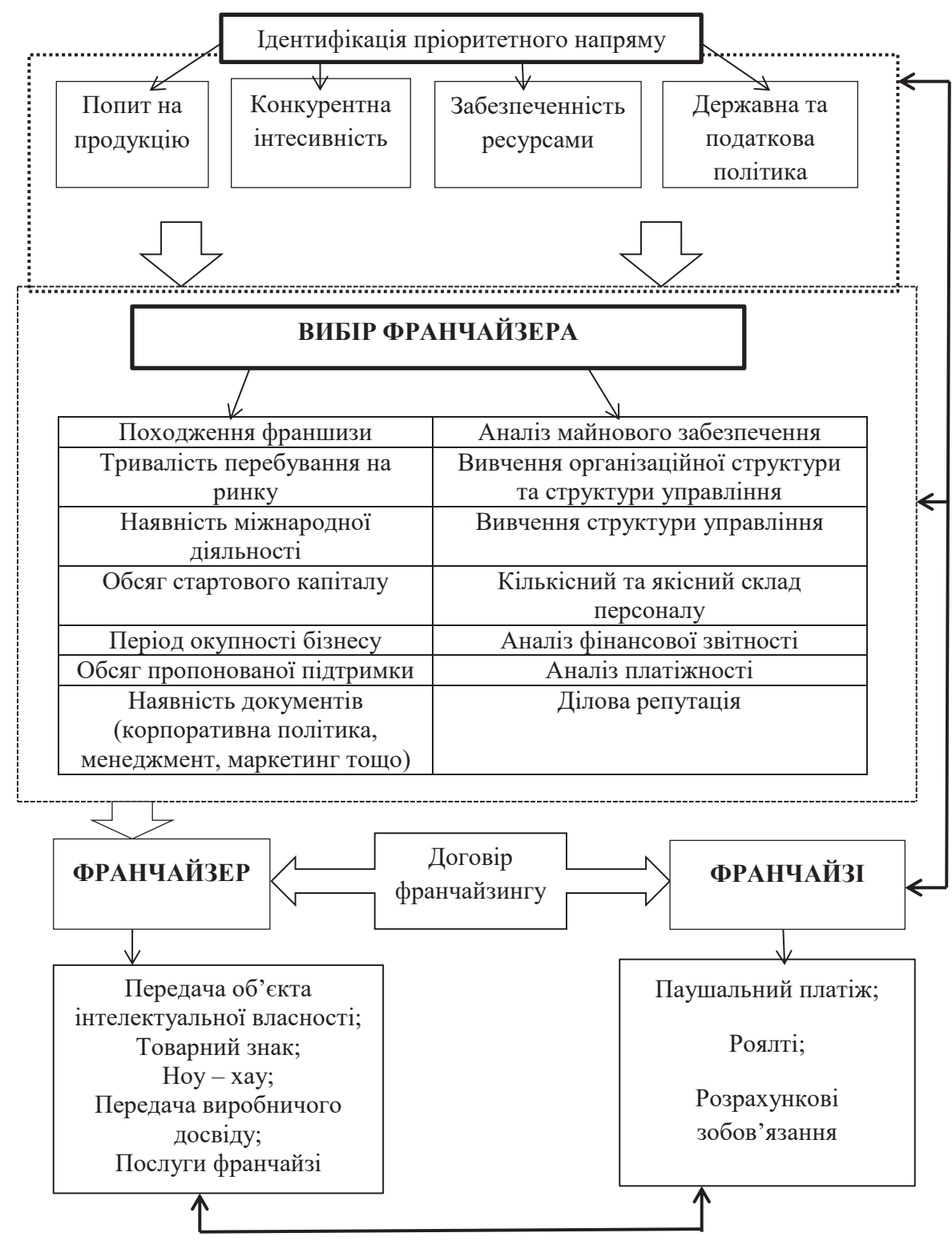

Рисунок 2 - Організаційна система франчайзингових відносин зера тощо. Окрім того, доцільно провести попередньо фінансово-економічний аналіз для оцінки франчайзингового потенціалу.

Реалізація сучасних бізнес-проектів вимагає широких знань у сфері управління, маркетингу, реклами та вміння враховувати особливості проекту. Настільки детальне розкриття інформації про франшизу забезпечує можливість потенційним франчайзі належною мірою оцінити усі переваги та недоліки, умови договору, фінансові витрати та можливі ризики. На жаль, вітчизняне законодавство не передбачає спеціальних вимог до розкриття франчайзерами інформації потенційним франчайзі, що ставить у невигідне положення насамперед франчайзі, вимушених сподіватися на добру волю франчайзера, який самостійно визначає, яку інформацію слід розкривати.

Отже, розроблення індивідуальних умов франчайзингової угоди є одним із найвідповідальніших та найважливіших етапів процесу організації франчайзингової співпраці, адже від їхньої коректності залежить подальша діяльність. На момент підписання франчайзингової угоди здійснюються початкові платежі франчайзі, підбір персоналу, обладнання, приміщення, відкриття франчайзингового закладу [10].

Франчайзинг як ефективна форма комерціалізації інтелектуальної власності є вигідним, малозатратним інструментом розвитку малого та середнього бізнесу. Ефективність цієї форми ведення бізнесу полягає в мінімізації операційних ризиків та збільшення тривалості життєвого циклу компанії (у порівнянні: свій бізнес згортають більше $25 \%$ звичайних малих підприємств і тільки 5\% франчайзі) [9]. 3 іншого боку, окрім отримання прибутку, франчайзингові відносини сприяють інноваційному розвитку українських підприємств, оскільки, крім торговельної марки, франчайзі здобуває за певну винагороду нові технології, знання, досвід, імідж франчайзера.

Як зазначено у дослідженні Н.С. Ситник, Д.В. Попович [5], популяр-ність франчайзингу спричинена такими чинниками:

1) купуючи бізнес, франчайзі отримує майже абсолютну підтримку 3 боку франчайзера - напрацьовані технології, рекламу, бренд і низку послуг, які надаються відповідно до умов певної франшизи. Франчайзі отримує інформацію, що допомагає зна- 
йти місце розташування підприємства, сформувати його стиль і забезпечити та проконтролювати функціонування. Завдяки отриманим уже основам, що здобув франчайзер, покупець знижує ризик провалу на початковій стадії свого проекту;

2) франчайзеру така угода дає інвестиції, необхідні для розвитку, регіони для роботи [5].

Франчайзингова схема вигідна для обох сторін, наприклад для фран-чазера на певному етапі розвитку компанії доцільно продавати франшизи і в майбутньому отримувати щомісяця відсотки з франчайзі, мінімізувати власні фінансові витрати, франчайзі можуть стати іноземні підприємці, що суттєво розширює коло потенційних клієнтів; для франчайзі - франшиза не завжди коштує дешевше, проте вона більш перспективна, бізнес будується вже за відпрацьованою стратегією, що гарантує успіх; франчайзери навчають, проводять тренінги, майстер-класи, тим самим допомагають майбутнім франчайзі вникнути в усі нюанси майбутнього бізнесу, франчайзинг передбачає постійну підтримку для запобігання здійсненню помилок; франчайзі, придбавши франшизу, залишається самостійним власником бізнесу, який зацікавлений у прибутковості його функціонування. Франчайзі сам займається управлінням і контролем роботи об'єкта.

Попри низки переваг, безумовно, є і негативні сторони, наприклад для франчайзера - неможливість контролювати якість виконання робіт, ризики розголошення корпоративної конфіденційної інформації; за рахунок високої ціни франшизи недостатньо претендентів, одержання невчасно платежів від франчайзі тощо; для франчайзі - постійний контроль, втрата повної свободи у визначені асортименту, можлива відсутність підтримки від франчайзера, велика сума коштів на придбання франшизи, переобладнання, виплату відсотків із доходу, неможливість швидкого виходу з бізнесу, адже, як правило, угода складається на тривалий строк; залежність від фінансової стабільності франчазера [11].

Висновки. Для вітчизняної економіки ведення бізнесу в умовах франчайзингової стратегії важливе як на рівні країни, так і на рівні підприємств задля поширення науково-технічного обміну. На державному рівні нерівномірний розвиток країн у науково-технічному розвитку пояснюється насамперед різними витратами на науково-технічні роботи. Промислово розвинені країни переслідують такі цілі, як модернізація виробництва, збільшення своїх потужностей, тоді як для країн, що розвиваються, - це можливість подолати відсталість у технологічному розвитку та збільшити власне виробництво для забезпечення внутрішнього попиту. Поширюючи передові технології за допомогою франчайзингу, можливо зменшити існуючі нерівності, сприяючи обміну новими розробками в досить нетривалий проміжок часу, без залучення великої кількості коштів.

Необхідно відзначити, що $є$ низка проблем, що перешкоджають роз-витку франчайзингу, які потребують вирішення юридичних, економічних, організаційних питань тощо. Це проблеми, пов'язані із необізнаністю вітчизняних підприємців 3 основними принципами та особливостями ведення бізнесу за умовами франчайзингу, невідповідністю міжнародним стандартам, недостатньою законодавчою базою України про франчайзинг, високою вартістю франшизи порівняно з купівельною спроможністю покупців, складними умовами та адміністративними бар'єрами для організації та ведення бізнесу. Отже, франчайзингові партнерські відносини - це система взаємозв'язку між різними суб'єктами господарювання, в якій елементи знаходяться в різноманітних, проте рівнозначних зв'язках, головним відображенням цього зв'язку є франчайзингова угода, за допомогою якої і визначають спрямованість співпраці між франчайзером і франчайзі.

\section{Список використаних джерел:}

1. Franchise group. URL: https://franchisegroup.com.ua/ru/ (дата звернення 10.06.2020).

2. Бившева Л.О., Кондратенко О.О., Лисенко А.О. Франчайзинг як ефективна форма розвитку інноваційного підприємництва в Україні Економічний вісник Донбасу № 3(53), 2018: електрон. версія журналу URL: http://dspace.nbuv.gov.ua/bitstream/handle/123456789/143518/23-Byvsheva.pdf?sequence=1 (дата звернення 10.06.2020).

3. Господарський кодекс України: Закон України від 16.01.2003 № 436-IV. (Дата оновлення: 17.06.2018). URL: http://zakon3.rada.gov.ua/ laws/show/436-15 (дата звернення: 07.06.2020)

4. Цивільний кодекс України: Закон України від 16.01.2003 p. № 435-IV. (Дата оновлення: 02.08.2018). URL: http://zakon0.rada.gov.ua/laws/ show/435-15 (дата звернення: 07.06.2020).

5. Ситник Н.С., Попович Д.В. Розвиток франчайзингу в Україні як складник інвестиційної політики держави. Бізнес-навіzamop. - 2018. - Bun.1(2). - C. 140 - 144. URL: http://nbuv.gov.ua/UJRN/bnav_2018 1(2) 31. (дата звернення 5.06.2020).

6. Franchising Code of Ethics. Ukrainian Federation of franchise development. Retrivied from. URL: http://fdf.org.ua/aboutfranchise/kodeks-etiki-franchajzingu in Ukrainian ( дата звернення 01.06.2020).

7. Регламент Комісії (СС) № 330/2010 від 20 квітня 2010 p. URL: www.buh24.com.ua/reglament-komisiyi-yes- 330-2010-vid20-kvitnya-2010-r/. (дата звернення 25.05.2020)

8. Офіційний сайт Європейської федерації франчайзингу URL: http://www.eff-franchise.com (дата звернення 25.05.2020).

9. Franchise Industry Research. British Franchise Association. 2016. URL: http: //www.thebfa.org/about-franchising/franchisingindustry -research. (дата звернення 07.06.2020).

10. Филюк Г.М., Магомедова А.М. Організаційно-економічний механізм формування франчайзингових партнерських відносин між підприємствами в Україні. Теоретичні та прикладні питання економіки. - 2015. - Bип. 1. - C. 7-14. URL: http://nbuv.gov.ua/UJRN/Tppe_2015_1_3. ( дата звернення 25.05.2020).

11. Гессен А.С., Журавель М.О., Стаханова В.В. Розвиток франчайзингу як вагомий фактор розширення ринку в Україні. Глобальніта національні проблеми економіки. URL: http://global-national.in.ua/issue-14-2016/22-vipusk-14-gruden-2016-r/2560gessen-a-e-zhuravel-m-o-stakhanova-v-v-rozvitok-franchajzingu-yak-vagomij-faktor-rozshirennya-rinku-v-ukrajini (дата звернення 01.06.2020). 


\section{References:}

1. Franchise group. Available at:: https://franchisegroup.com.ua/ru/( accessed 10 June 2020).

2. Byvsheva L.O., Kondratenko O.O., Lysenko A.O.(2018) Franchajzyngh jak efektyvna forma rozvytku innovacijnogho pidpryjemnyctva v Ukrajini [Franchising as an effective form of development of innovative entrepreneurship in Ukraine] Ekonomichnyj visnykDonbasu vol. 3 no.(53): elektron. versijazhurnaluAvailable at: http://dspace.nbuv.gov.ua/bitstream/handle/123456789/143518/23Byvsheva.pdf? sequence $=1$ (accessed 10 June 2020).

3. Ghospodarsjkyj kodeks Ukrajiny: Zakon Ukrajiny vid 16.01.2003 \# 436-IV. (Data onovlennja: 17.06.2018). Available at: http://zakon3.rada.gov.ua/ laws/show/436-15(accessed 7 June 2020).

4. Cyviljnyj kodeks Ukrajiny: Zakon Ukrajiny vid 16.01.2003 r. \# 435-IV. (Data onovlennja: 02.08.2018). Available at: http://zakon0.rada.gov.ua/laws/ show/435-15(accessed7 June 2020).

5. Sytnyk N.S., Popovych D.V. (2018)Rozvytok franchajzynghu v Ukrajini jak skladnyk investycijnoji polityky derzhavy[Development of franchising in Ukraine as a component of state investment policy] Biznes - navighator. - Vol.1 no(2). pp.140 - 144. Available at: http://nbuv.gov.ua/UJRN/bnav_2018_1(2)_31. (accessed 5 June 2020).

6. Franchising Code of Ethics. Ukrainian Federation of franchise development. Retrivied from. Available at: http://fdf.org.ua/ about-franchise/kodeks-etiki-franchajzingu in Ukrainian (accessed 1 June 2020).

7. Rehlament Komisiyi (YeS) (2010) \# 330/2010 Available at: www.buh24.com.ua/reglament-komisiyi-yes- 330-2010-vid-20kvitnya-2010-r/ (accessed 25 May June 2020).

8. Ofitsiynyy sayt Yevropeys'koyi federatsiyi franchayzynhu Available at: http://www.eff-franchise.com (accessed 25 May June 2020).

9. Franchise Industry Research. British Franchise Association. 2016. Available at: http: //www.thebfa.org/about-franchising/ franchising-industry -research (accessed 7 June 2020).

10. Fylyuk H.M., Mahomedova A.M. (2015) Orhanizatsiyno - ekonomichnyy mekhanizm formuvannya franchayzynhovykh partners'kykh vidnosyn mizh pidpryyemstvamy v Ukrayini[Organizational and economic mechanism of formation of franchising partnerships between enterprises in Ukraine] Teoretychni ta prykladni pytannya ekonomiky. - Vol. 1. - pp. 7-14. Available at: http://nbuv.gov.ua/UJRN/Tppe 2015 1 3. (accessed 25 May June 2020).

11. Ghessen A.Je., Zhuravelj M.O., Stakhanova V.V. Rozvytok franchajzynghu jak vaghomyj faktor rozshyrennja rynku v Ukrajini. [Development of franchising as an important factor in market expansion in Ukraine] Ghlobaljnita nacionaljni problemy ekonomiky Available at: http://global-national.in.ua/issue-14-2016/22-vipusk-14-gruden-2016-r/2560-gessen-a-e-zhuravel-m-o-stakhanova-v-vrozvitok-franchajzingu-yak-vagomij-faktor-rozshirennya-rinku-v-ukrajini (accessed 01 June 2020).

Prysvitla Oksana

Dnipro State Technical University

\section{FRANCHISING: THE ESSENCE AND ORGANIZATIONAL ORDER OF PARTHERS' RELATIONSHIPS REFLECTION}

This article is devoted to the problems and prospects of the franchising devel-opment in Ukraine. As the state economic policy, which is characterized by in-stability and unpredictability, in particular in the sphere of innovative invest-ment policy, and also the lack of detailed legal support restrain the process of the franchising partnership. It should be mentioned, that all the stated above restrain the technology transfer development as an innovative product able to provide both the rise in competitiveness of economic activity and an export potential of the state economy in whole. In modern conditions the world economy is characterized by a high level of globalization and integration. That's why it is becoming an actual task to boost economic activity, while the improvement of close trade, investment and coop-erative partnership will promote including Ukraine into the process of forming of new models of economic development and the base for them will be continuous renewal of economic systems based on the technological modernization. Besides, the successful development of the innovative component of home economics is a source of the involvement of innovations, investments, know-how and also open channels to transfer knowledge and technologies. Unconventional methods of financing innovative activity are becoming actual, franchising is among them. Besides, franchising is an element of support for small-and medium-sized business and an effective lever of cooperation of big and small business in Ukraine. The article covers the substance of the franchising relationships mechanism in Ukraine. It substantiates the necessity and efficiency of the business organization on conditions of franchising for the growth of the scientific and technical progress. The article researches the organizational mechanism of forming the franchising relationships. It determines the main components of the franchising relationships, their peculiarities. The research highlights the main problems of the franchising relationships functioning in the context of modern development of the home economy. It defines the advantages and disadvantages for the main subjects of franchising relationships.

Key words: franchising, franchisor, franchisees, franchising relationship, organ-izational mechanism of franchising.

JEL classification: F63, L26, M21, O19, O33 